\title{
Pengaruh Tingkat Kematangan Buah Terhadap Viabilitas Benih Kopi (Coffea robusta L.)
}

\author{
Nani Rohaeni ${ }^{1}$ dan Farida ${ }^{2}$ \\ 1,2 Program Studi Agroteknologi Sekolah Tinggi Pertanian Kutai Timur, Jl. Soekarno-Hatta, \\ Sangatta Utara Kutai Timur, 75611. \\ ${ }^{1}$ Email : nanirohaeni@stiperkutim.ac.id \\ 2Email : farida@stiperkutim.ac.id
}

\begin{abstract}
This research aims to find out the level of fruit maturity of coffee on seed viability. Knowing the best coffee maturity level for germination. This research was conducted in December 2017 until march 2018. This research located at Jl. Poros Kabo Gang Bumi Taka Swarga Bara Sangatta Kutai Timur. Using Completely Randomized Design (RAL) non factorial, repeated 5 repetitions. The fruit maturity factor (M) consists of M1 = Chocolate, $M 2$ = Red, M3 = Yellowish Red, M4 = Yellow. M5 = Greenish Yellow, to know the effect of treatment then conducted analysis of varience and if there is a real influence then proceed with BNT test level $5 \%$. The results showed that fruit maturity level influenced the viability of seeds, and the red coffee indicates the best level of maturity.
\end{abstract}

Keywords: Coffee, Fruit color, Fruit maturity, Seed viability, Variance analysis.

\begin{abstract}
ABSTRAK
Penelitian ini bertujuan untuk mengetahui pengaruh tingkat kematangan buah kopi terhadap viabilitas benih, dan mengetahui tingkat kematangan buah kopi yang terbaik untuk dikecambahkan. Penelitian ini dilaksanakan pada bulan Desember 2017 sampai bulan Maret 2018. Penelitian ini bertempat di Jl. Poros Kabo Gang Bumi Taka Swarga Bara Sangatta Kutai Timur. Menggunakan Rancangan Acak Lengkap (RAL) non faktorial, yang diulang sebanyak 5 kali ulangan. Faktor tingkat kematangan buah (M) terdiri dari M1 = Coklat, M2 = Merah, M3 = Merah kekuningan, M4 = Kuning, M5 = Kuning Kehijauan, untuk mengetahui pengaruh perlakuan maka dilakukan analisis sidik ragam dan bila terdapat pengaruh yang nyata maka dilanjutkan dengan uji BNT taraf $5 \%$. Hasil penelitian menunjukkan bahwa tingkat kematangan buah berpengaruh terhadap viabilitas benih, dan tingkat kematangan buah kopi warna merah menunjukkan yang terbaik.
\end{abstract}

Kata kunci: Analisis sidik ragam, Kematangan buah, Kopi, viabilitas, Warna buah.

\section{Pendahuluan}

Kopi merupakan salah satu jenis tanaman perkebunan yang sudah lama dibudidayakan dan memiliki nilai ekonomis yang lumayan tinggi. Konsumsi kopi dunia mencapai $70 \%$ berasal dari spesies kopi Arabika dan 30\% berasal dari spesies kopi Robusta. Kopi berasal dari Afrika, yaitu daerah pegunungan di Etopia. Kopi sendiri baru dikenal oleh masyarakat dunia setelah tanaman tersebut dikembangkan di luar daerah asalnya, yaitu Yaman di bagian selatan Arab, melalui para saudagar Arab (Sembiring, 2015).

Negara Indonesia memiliki kualitas kopi arabika maupun robusta yang sangat baik. Sejak tahun 1970, 10\% dari bahan yang diekspor ke luar negeri adalah kopi. Negara-negara yang paling banyak mengimpor kopi Indonesia antara lain Jepang, Eropa bagian barat dan timur, Amerika Serikat, Afrika Utara, dan Timur Tengah. Setiap 
tahunnya produksi kopi Indonesia mengalami penurunan mulai dari 2012-2017 dapat diambil rata-rata 3.395.874,5 ton/ha (BPS, 2017).

Data statistik perkebunan kopi tahun 2015-2017 Kalimantan Timur, produksi kopi robusta maupun kopi arabika mengalami penurunan baik luas areal kebun maupun produksinya mulai dari 2015 yaitu 339 ton/ha sedangkan hasil produksi pada tahun 2016 kebun kopi menghasilkan 226 ton/ha (BPS, 2017).

Kendala dalam menghasilkan benih yang berkualitas adalah dari penyediaan benih. Proses menghasilkan benih diperlukan persyaratan lainnya, yaitu benih harus mempunyai potensi genetik yang baik dan dipanen tepat waktu agar memiliki kualitas fisiologis benih yang baik (Saefudin, 2013).

Kualitas benih ditunjukkan oleh viabilitas dan vigor. Viabilitas dan vigor benih dipengaruhi oleh tingkat kematangan benih. Menurut Ichsan et.al., (2013) kematangan benih mempengaruhi daya berkecambah dan kecepatan tumbuh. Benih yang dipanen sebelum masak fisiologis belum memiliki cadangan makanan yang cukup dan embrionya belum sempurna. Hal ini akan mempengaruhi viabilitas benih (Sutopo, 2002). Benih yang dipanen saat buah masak fisiologis memiliki kualitas terbaik untuk dijadikan benih (Ichsan et.al., 2013).

Upaya percepatan proses perkecambahan adalah dengan penerapan berdasarkan tingkat kematangan buah dalam memproduksi benih kopi secara komersial maka direkomendasikan untuk panen buah yang telah matang (Saefudin, 2013).

Berdasarkan uraian diatas peneliti mencoba untuk melakukan percobaan mengenai pengaruh tingkat kematangan buah terhadap kemampuan tumbuh benih (viabilitas). Tujuan dari penelitian ini adalah mengetahui pengaruh tingkat kematangan buah terhadap viabilitas benih kopi dan mengetahui kematangan buah yang terbaik terhadap viabilitas benih kopi.

\section{Metodologi Penelitian}

\section{Waktu dan Tempat}

Penetian ini dilaksanakan pada bulan Agustus sampai November 2019 terhitung dari persiapan awal. Penelitian ini bertempat di Jl. Poros Kabo Gang Bumi Taka Swarga Bara Sangatta Kutai Timur.

\section{Alat dan Bahan}

Alat yang digunakan dalam penelitian ini adalah cangkul, gembor, bak semai, meteran alat tulis dan kamera, sedangkan bahan yang digunakan adalah benih kopi liberika, pasir, topsoil dan Dithane 45, abu dapur. 


\section{Metode Penelitian}

Metode yang digunakan dalam penelitian ini adalah Rancangan Acak Lengkap (RAL) dengan 5 taraf perlakuan setiap perlakuan diulang sebanyak 5 kali ulangan bisa dilihat sebagai berikut : M1 = Coklat; $M 2$ = Merah; M3 = Merah kekuningan; M4 = Kuning; M5 = Kuning Kehijauan

Pelaksanaan penelitian ini meliputi :

\section{Persiapan tempat perkecambahan}

Persiapan tempat perkecambahan ini meliputi bak semai yang terbuat dari kayu yang berbentuk kotak, kemudian dilakukan pengisian pasir dicampur topsoil perbandingan $1: 1$

2. Persiapan benih untuk penelitian

Biji kopi diambil dari pohon kemudian dipisahkan berdasarkan tingkat kematangan buah yaitu : coklat, merah, merah kekuningan, kuning dan kuning kehijauan. Buah kopi dikupas, kemudian ambil bijinya. Biji yang digunakan sebagai benih dibersihkan lapisan lendirnya dengan abu dapur, lalu cuci bersih dan direndam dalam Dhitane 45 sekitar 5 menit.

\section{Penanaman}

Semua biji dibenamkan pada lapisan pasir menghadap ke bawah, artinya bagian punggung di atas, dan bagian perut menghadap ke bawah. Biji dibenamkan secara berderet dalam satu baris, jarak antara baris larikan yang satu dengan lainnya $4 \mathrm{~cm}$. Sedangkan jarak antara biji dengan biji $3 \mathrm{~cm}$.

4. Pemeliharan

Pemeliharaan benih kopi ini meliputi penyiraman pada pagi hari dan sore hari, sedangkan penyiangan gulma yang tumbuh disekitar persemaian dilakukan seminggu sekali.

Parameter penelitian meliputi :

\section{Persentase biji berkecambah (\%)}

Presentase perkecambahan dihitung dengan rumus:

$$
\% \text { perkecambahan }=\frac{\text { jumlah kecambah normal yang dihasilkan }}{\text { jumlah contoh benih yang diuji }} \times 100 \%
$$

2. Laju perkecambahan (hari)

Laju perkecambahan dapat diukur dengan menghitung jumlah hari yang diperlukan untuk munculnya radikel atau planula (Sutopo, 2012)

$$
\text { Rata }- \text { rata hari }=\frac{N_{1} T_{1}+N_{2} T_{2}+\ldots N_{X} T_{X}}{\text { jumlah total benih yang berkecambah }}
$$


Indeks kecepatan perkecambahan dihitung menggunakan rumus menurut Kartasaputra (2003) sebagai berikut:

$$
\mathrm{IV}=\frac{\mathrm{G} 1}{\mathrm{D} 1}+\frac{\mathrm{G} 2}{\mathrm{D} 2}+\frac{\mathrm{G} 3}{\mathrm{D} 3}+\frac{\mathrm{G} 4}{\mathrm{D} 4}+\cdots \frac{\mathrm{Gn}}{\mathrm{Dn}}
$$

Dimana:

IV = Indeks Vigor

$\mathrm{G}=$ Jumlah benih yang berkecambah pada hari tertentu

$\mathrm{D}=$ Waktu yang bersesuaian dengan jumlah tersebut

$\mathrm{N}=$ Jumlah hari pada perhitungan akhir

4. Panjang tunas $(\mathrm{cm})$

Pengukuran panjang tunas dilakukan pada umur 3 bulan setelah tanam dengan menggunakan meteran. Pengukuran panjang tunas dari permukaan tanah sampai titik tumbuh.

5. Volume kecambah (ml)

Dalam pengamatan volume kecambah $(\mathrm{ml})$ dilakukan pada umur 3 bulan setelah tanam dengan menggunakan gelas erlemeyer. Terlebih dahulu gelas erlemeyer diisi dengan aquades setinggi $50 \mathrm{ml}$ kemudian masukkan kecambah kopi ke dalam gelas erlemeyer tersebut. Volume kecambah dihitung dengan rumus : Volume kecambah kopi = volume akhir - volume awal $(50 \mathrm{ml})$.

Analisis Data

Data yang diperoleh dari hasil penelitian dianalisis ragam pada taraf $5 \%$ dan bila terdapat pengaruh yang nyata dilanjutkan dengan uji Beda Nyata Terkecil (BNT) pada taraf $5 \%$.

\section{Hasil dan Pembahasan \\ Presentase Perkecambahan}

Hasil penelitian pengaruh tingkat kematangan buah terhadap rata-rata presentase perkecambahan biji kopi dapat dilihat pada Tabel 1 dibawah ini.

\begin{tabular}{cc}
\multicolumn{2}{c}{ Tabel 1. Presentase perkecambahan biji kopi (\%) } \\
\hline Perlakuan & Presentase Perkecambahan(\%) \\
\hline M1 (coklat) & $70,000 \mathrm{a}$ \\
M2 (merah) & $100,000 \mathrm{~b}$ \\
M3 (merah kekuningan) & $76,000 \mathrm{a}$ \\
M4 (kuning) & $62,000 \mathrm{a}$ \\
M5 (kuning kehijauan) & $76,000 \mathrm{a}$ \\
\hline Keterangan : angka rata-rata yang diikuti oleh huruf yang sama \\
berarti menunjukkan tidak berbeda nyata pada uji \\
BNT taraf $5 \%=17,503$
\end{tabular}

Rata-rata presentase perkecambahan tertinggi adalah M2 (merah) yaitu 100\%, hal ini diduga oleh tingkat kematangan buah merah dimana merupakan stadia pemasakan biji terbaik untuk memicu perkecambahan, sesuai pendapat Icshan (2013) ada dua faktor 
ISSN 2354-7251 (print)

yang mempengaruhi perkecambahan benih yaitu dari faktor dalam (tingkat kemasakan benih, ukuran benih, dormansi) dan faktor luar (air, temperatur, oksigen dan cahaya).

Buah yang berwarna merah sudah mencapai masak fisiologis sempurna, sehingga kandungan nutrisi (karbohidrat, protein dan lemak) sebagai sumber energi di dalam biji sudah siap untuk digunakan berkecambah Setyowaty et.al (2008).

Utami dan Setyowaty et.al., (2008) melaporkan bahwa tingkat ketuaan benih mempengaruhi kecepatan dan daya berkecambah palem putri, persentase perkecambahan tertinggi diperoleh pada benih tua. Pendapat tersebut diperkuat oleh Veiga et.al., 2007 dan Saefudin \& Wardiana (2013) memproduksi benih kopi secara komersial maka direkomendasikan untuk panen buah yang telah matang penuh yaitu pada tahap warna buah merah (tingkat cherry), karena buah yang dipanen dengan kriteria tersebut dapat menghasilkan nilai perkecambahan dan vigor benih yang lebih baik dibandingkan warna buah kuning kehijauan.

\section{Laju Perkecambahan (hari)}

Hasil penelitian pengaruh tingkat kematangan buah terhadap rata-rata laju perkecambahan biji kopi dapat dilihat pada Tabel 2 dibawah ini.

Tabel 2. Laju perkecambahan (hari)

\begin{tabular}{cc}
\hline Perlakuan & Laju perkecambahan(hari) \\
\hline M1 (coklat) & $23,000 \mathrm{a}$ \\
M2 (merah) & $19,160 \mathrm{a}$ \\
M3 (merah kekuningan) & $26,079 \mathrm{~b}$ \\
M4 (kuning) & $27,636 \mathrm{c}$ \\
M5 (kuning kehijauan) & $27,178 \mathrm{~b}$ \\
\hline Keterangan : angka rata-rata yang diikuti oleh huruf yang \\
sama berarti menunjukkan tidak berbeda \\
nyata pada ujian BNT taraf $5 \%=4,395$
\end{tabular}

Hasil pengamatan rata-rata laju perkecambahan biji kopi menunjukkan bahwa perlakuan M2 (merah) menunjukkan bahwa laju perkecambahan yang paling cepat sejalan dengan presentase perkecambahan, hal ini diduga perlakuan M2 (Merah) sudah mengalami peristiwa-peristiwa fisiologis biji sehingga viabilitas benih sangat tinggi.

Pendapat Subandi (2013). perkecambahan meliputi peristiwa-peristiwa fisiologis dan morfologis antara lain imbibisi dan absorbsi air, hidrasi jaringan, pengaktifan enzim, transpor molekul yang terhidrolisis ke sumbu embrio, peningkatan respirasi dan asimilasi, inisiasi pembelahan dan pembesaran sel, serta munculnya embrio.

\section{Indeks Vigor}

Hasil penelitian pengaruh tingkat kematangan buah terhadap rata-rata indeks vigor biji kopi dapat dilihat pada Tabel 3. Hasil penelitian tentang pengaruh tingkat kematangan buah terhadap viabilitas benih menunjukkan indeks vigor perlakuan M2 (merah) paling baik keseragaman perkecambahannya sehingga biji kopi dapat tumbuh seragam hal ini sejalan dengan laju perkecambahan karena benih menunjukkan bahwa kemasakan fisiologis dapat menumbuhkan benih secara secara normal berpengaruh 
pada indeks vigor benih. Kecepatan atau laju perkecambahan benih berhubungan erat dengan vigor tanaman yaitu bahwa benih dengan indeks vigor yang tinggi akan menghasilkan tanaman yang lebih tahan terhadap keadaan lingkungan yang kurang menguntungkan Marthen dan Rehatta (2013).

Tabel 3. Indeks vigor biji kopi

\begin{tabular}{cc}
\hline Perlakuan & Indeks Vigor \\
\hline M1 (coklat) & $0,316 \mathrm{ab}$ \\
M2 (merah) & $0,564 \mathrm{c}$ \\
M3 (merah kekuningan) & $0,302 \mathrm{ab}$ \\
M4 (kuning) & $0,241 \mathrm{a}$ \\
M5 (kuning kehijauan) & $0,307 \mathrm{ab}$ \\
\hline Keterangan : angka rata-rata yang diikuti oleh \\
huruf yang sama berarti \\
menunjukkan tidak berbeda \\
nyata pada ujian BNT taraf $5 \%=$ \\
0,110
\end{tabular}

Hal yang sama juga dikatakan oleh Marthen dan Rehatta (2013) bahwa benih yang mempunyai kecepatan perkecambahan yang tinggi, akan menghasilkan tanaman yang tahan terhadap keadaan lingkungan. Hal ini sesuai dengan Sutopo (2002) bahwa benih yang dipanen sebelum masak fisiologis dicapai mempunyai viabilitas yang rendah karena belum memiliki cadangan makanan yang cukup dan pembentukan embrio belum sempurna.

\section{Panjang Tunas (cm)}

Hasil penelitian pengaruh tingkat kematangan buah terhadap rata-rata panjang tunas biji kopi dapat dilihat pada Tabel 4 di bawah ini.

Tabel 4. Panjang tunas dan panjang akar biji kopi (cm)

\begin{tabular}{cc}
\hline Perlakuan & Panjang Tunas \\
\hline M1 (coklat) & 6,64 \\
M2 (merah) & 7,36 \\
M3 (merah kekuningan) & 6,84 \\
M4 (kuning) & 6,99 \\
M5 (kuning kehijauan) & 7,15 \\
\hline
\end{tabular}

Parameter panjang tunas tidak terdapat pengaruh nyata terhadap perlakuan diduga karena perkecambahan yang telah terjadi tidak didukung penerimaan cahaya matahari yang mencukupi. Tumbuhan yang diletakkan ditempat gelap akan tumbuh lebih cepat daripada yang diletakkan di tempat yang terkena cahaya akan tetapi tumbuhan menjadi pucat karena kekurangan klorofil, kurus, dan daun tidak berkembang. Tumbuhan seperti itu disebut mengalami etiolasi. Dalam keadaan tidak ada cahaya, auksin merangsang pemanjangan sel-sel sehingga tumbuh lebih panjang. Sebaliknya dalam keadaan banyak cahaya auksin mengalami kerusakan sehingga pertumbuhan tumbuhan terhambat. Cahaya menyebabkan auksin rusak terdispersi ke sisi gelap. Laju tumbuh memanjang pada tumbuhan dengan segera berkurang sehingga batang lebih pendek, namun tumbuhan lebih kokoh, daun berkembang sempurna, dan berwarna hijau. Selain berpengaruh pada pertumbuhan tanaman, cahaya dibutuhkan dalam proses fotosintesis. 
ISSN 2354-7251 (print)

Tumbuhan yang tidak terkena cahaya tidak dapat membentuk klorofil sehingga daun menjadi pucat. Akan tetapi, jika intensitas cahaya terlalu tinggi, klorofil akan rusak.

\section{Volume Perkecambahan ( $\mathrm{ml})$}

Hasil penelitian pengaruh tingkat kematangan buah terhadap rata-rata volume perkecambahan benih kopi dapat dilihat pada Tabel 5.

Tabel 5. Volume perkecambahan kopi (ml).

\begin{tabular}{cc}
\hline Perlakuan & Panjang Tunas \\
\hline M1 (coklat) & $6,68 \mathrm{a}$ \\
M2 (merah) & $8,26 \mathrm{abc}$ \\
M3 (merah kekuningan) & $7,23 \mathrm{ab}$ \\
M4 (kuning) & $8,94 \mathrm{bc}$ \\
M5 (kuning kehijauan) & $9,64 \mathrm{c}$ \\
\hline Keterangan : Angka rata-rata yang diikuti oleh \\
huruf yang sama berarti \\
menunjukkan tidak berbeda \\
nyata pada ujian BNT taraf $5 \%=$ \\
1,832.
\end{tabular}

Pertumbuhan M4 dan M5 memiliki rata-rata volume perkecambahan benih lebih tinggi dibandingkan dengan pertumbuhan lainnya diduga karena perubahan kuantitatif di dalam sel, jaringan dan organ genetik pada benih kopi yang mengalami perkembangan sel. Menurut Kusumaningrum (2007) mengatakan bahwa pertumbuhan tidak berlangsung secara seragam pada seluruh bagian tanaman. Pertumbuhan dimungkinkan terfokus pada jaringan meristem batang sehingga pembesaran sel yang dihasilkan dari pembelahan sel tersebut yang menyebabkan pertambahan ukuran tanaman. Pertumbuhan berarti pertambahan ukuran. Karena organisme multisel tumbuh dari zigot, pertambahan ini bukan hanya dalam volume, tetapi juga dalam bobot, jumlah sel, banyaknya protoplasma dan tingkat kerumitan (Salisbury dan Ross, 1995).

Pertumbuhan yang terjadi di dalam benih kopi diikuti dengan perkembangan sel dan volume. Perkembangan mewujudkan perubahan dan perubahan-perubahan tersebut dapat berjalan secara bertahap atau berjalan sangat cepat. Pada perkembangan tidak hanya perubahan kuantitatif, tetapi juga menyangkut perubahan kualitatif di antara sel, jaringan dan organ yang disebut diferensiasi peryataan Luqman (2012). Selain media tumbuh faktor lingkungan juga sangat mempengaruhi volume perkecambahan media tumbuh, faktor lingkungan juga perlu diperhatikan, misalnya suhu, kelembaban udara dan intensitas cahaya. Faktor lingkungan ini mempengaruhi laju pertumbuhan (laju akumulasi bahan kering) dan laju perkembangan tanaman (laju perkembangan dari fase satu ke fase yang lain) (Putri, 2006).

\section{$4 \quad$ Kesimpulan}

Kesimpulan dari penelitian ini adalah tingkat kematangan buah kopi berwarna merah (M2) menunjukkan hasil yang terbaik, karena menghasilkan presentase 
perkecambahan sebesar 100,00\%, laju perkecambahan tercepat sebesar 19,160 hari dan indeks vigor sebesar 0,564 IV.

\section{Daftar Pustaka}

Subandi, A. E. (2013). Aktivitas Endo-B-Mannanase Pada Perkecambahan Biji Parkia Roxburghii G. Don Dengan Pemberian Variasi Konsentrasi Giberelin. Doctoral dissertation. Universitas Sebelas Maret.

BPS. (2017). Sekretariat Direktorat Jenderal Perkebunan. Kementerian Pertanian. http://ditjenbun.pertanian.go.id.

Putri, D. M. S. (2006). Pengaruh Jenis Media terhadap Pertumbuhan Begonia Imperialis dan Begonia 'Bethlehem Star'. Biodiversitas, 7(2), 168-170.

Ichsan, C. N. I. N., Hereri, A. I., \& Budiarti, L. (2013). Kajian Warna Buah Dan Ukuran Benih Terhadap Viabilitas Benih Kopi Arabika (Coffea arabica L.) varietas Gayo 1. Jurnal Floratek, 8(2), 110-117.

Kusumaningrum, I., Hastuti, R. B., \& Haryanti, S. (2007). Pengaruh Perasan Sargassum Crassifolium Dengan Konsentrasi Yang Berbeda Terhadap Pertumbuhan Tanaman Kedelai (Glycine max (I) merill). Anatomi Fisiologi, 15(2), 7-13.

Marthen, E. K., \& Rehatta, H. (2013). Pengaruh Perlakuan Pencelupan dan Perendaman Terhadap Perkecambahan Benih Sengon (Paraserianthes falcataria L.). Agrologia. Jurnal Ilmu Budidaya Tanaman, 2(1), 10-16.

Saefudin, S., \& Wardiana, E. (2013). Pengaruh Varietas dan Tingkat Kematangan Buah terhadap Perkecambahan dan Fisik Benih Kopi Arabika. Buletin Ristri, 4(3), 245256.

Salisbury, F. B., \& Ross, C. W. (1995). Fisiologi Tumbuhan. Bandung: ITB

Setyowati, N., \& Utami, N. W. (2008). Pengaruh Tingkat Ketuaan Buah, Perlakuan Perendaman Dengan Air Dan Larutan Ga3 Terhadap Perkecambahan Brucea javanica (L.) Merr. Biodiversitas, 9(1), 13-16.

Sutopo, L. (2002). Teknologi Benih. Jakarta: Raja Grafindo Persada.

Sembiring, S. A. (2015). Kajian Jumlah Biji Basah dan Berat Bji Basah Kopi Robusta (Coffea robusta Lindl.) Pada Beberapa Ketinggian, Kemiringan Lereng dan Jenis Tanah di Kecamatan Silima Pungga-Pungga Kabupaten Dairi. Agroekoteknologi, 4(1), 1857-1864. 